\title{
Utilization of unattended waste plastic oil as fuel in low heat rejection diesel engine
}

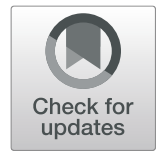

Sivakumar Ellappan ${ }^{*}$ and Bridjesh Pappula

\begin{abstract}
This experimental work analyzes the usage of 100\% of Waste Plastic Oil (WPO) in low heat rejection (LHR) diesel engine without diesel. For this purpose, the hardware components of conventional diesel engine were coated with lanthana-doped partially stabilised zirconia, to a thickness about $300 \mu \mathrm{m}$ by plasma spray coating technique. WPO was produced in a research facility scale setup by pyrolysis method. Coated and uncoated engines were tested with WPO and the outcomes were compared with diesel. Results authenticate the objective of this study and shows enhancement in performance and diminution in specific fuel utilization. The reduction in emission with exception of $\mathrm{NO}_{x}$ was noticed in lanthana-doped partially stabilised zirconia coated engine than that of uncoated diesel engine.
\end{abstract}

Keywords: Lanthana-doped partially-stabilized zirconia, Waste plastic oil, Performance, Emission

\section{Introduction}

Worldwide most suitable and usable power generation unit is diesel engine because of its high fuel conversion efficiency, reliability and robustness. Diesel engines were accepted in automobile, agricultural sectors due to their superior thermal efficiency and easiness of handling. Hence, the consumption of fossil fuel increased tremendously for the last 40 years. This increases the demand and cost of the fossil fuels. Burning of fossil fuel emits large amount of pollutants, which causes the air pollution and affect the environment severely [1-4]. In this regard, a viable solution for fossil fuel depletion and simultaneously addressing the reduction of engine exhaust gas emission can be found with alternate fuels. The use of vegetable oils in diesel engine has been enormously increased, as it can be produced in large scale and eco-friendly. However, utilization of vegetable oil directly in the diesel engine produces lower performance because of its higher viscosity. So transesterification process is required for reduction of viscosity of vegetable oil [5]. However, transesterification process does not improve the biodiesel properties as closer to diesel fuel. Several researchers have pointed out that blends of biodiesel and diesel have improved the performance and

* Correspondence: sivaarni1977@gmail.com Department of Mechanical Engineering, MLR Institute of Technology, Hyderabad 500043, India reduced the emission of diesel engine, but still the usage of diesel fuel is not minimized. On the onset, availability, predictability and storage are more difficult for biodiesel than other alternative fuels. Nowadays plastics are mostly used in industrial and household sectors due to its various attractive qualities and low cost. In spite of these advantages, the plastic wastes have large number of natural complexities. The enormous use of plastic has made a lot of waste plastic and it has ended up in all landfills. It presents a major issue in disposing them in view of their non-degradable nature [6, 7]. So, production of straight waste plastic oil (WPO) from waste plastic by pyrolysis process that can be used in diesel engine is a feasible solution. From this the dual benefit of getting energy from wastes and solving disposal problem can be achieved [8]. Kumar et al. reported that brake thermal efficiency (BTE) of WPO at all loads conditions was lower than that of diesel fuel [9]. Kaimal et al. reported that at higher load, thermal efficiency of WPO blends with diesel is lower than that of diesel because of its lower calorific value [10]. Gungor et al. evaluated the performance of multi-cylinder, combustion chambercompression ignition (CI) engine fueled by WPO. They found that BTE of engine has slightly decreased by using $100 \%$ WPO. Increase of carbon monoxide (CO) and oxides of nitrogen $\left(\mathrm{NO}_{\mathrm{x}}\right)$ was observed [11]. Panda et al. used WPO in diesel engine and they reported that 
engine power was reduced to $16 \%$ with a $20 \%$ blend and reduction of $50 \%$ with a $40 \%$ blend [12]. Mani et al. concluded that 100\% WPO can run the diesel engine without any modifications, but $\mathrm{CO}$ and hydro carbon $(\mathrm{HC})$ emissions were higher and smoke was decreased by $40 \%$ compared to diesel [13].

Lapuerta et al. tested the CI engine fueled by waste cooking oil mixed with diesel and reported that particulate matter (PM) was decreased at both low and medium load ranges and exhibited no progressions at higher loads [14].

The properties of WPO are almost similar to diesel fuel, although its performance in diesel engine is not comparable to diesel fuel. As a result, performance improvement technique is needed for better utilization of $100 \%$ WPO. Engine combustion components were often coated with thermal barrier coating (TBC) to get better engine performance and reduction of pollutant emissions [15]. Due to the ceramic coating on combustion chamber hardware, thermal efficiency has been increased through the reduction of heat rejection [16, 17]. Kumar et al. have tested the DI-CI engine powered by Pongamia pinnata oil blends with diesel. The combustion chamber hardware was coated with lanthanum doped partially stabilized zirconia zirconate over a bond coat of $\mathrm{NiCrAl}$ with thickness of 350 and $150 \mu \mathrm{m}$, respectively. They have concluded that brake specific fuel consumption (BSFC) decreased for lanthanum doped partially stabilized zirconia zirconate with B20 and B100 compared to diesel. Further $\mathrm{CO}, \mathrm{CO}_{2}$ emissions decreased and higher $\mathrm{NO}_{\mathrm{x}}$ emission was observed for coated engine [18]. Hazar and Ozturk have investigated the $\mathrm{CI}$ engine performance with the combustion chamber hardware coated with ceramic material, aluminum oxide $\left(\mathrm{Al}_{2} \mathrm{O}_{3}\right)$ and titanium oxide $\left(\mathrm{TiO}_{2}\right)$ by plasma spray coating process. Coated and uncoated engines were operated with corn oil methyl ester blends with diesel. They reported that engine power, specific fuel consumption, smoke density and $\mathrm{CO}$ emission were reduced and engine efficiency and $\mathrm{NO}_{\mathrm{x}}$ emission were increased compared to that of uncoated engine [19]. Table 1 shows the summary of low heat rejection (LHR) engine exhaust emissions compared to conventional engine fueled with biodiesel.

Literature review revealed that enhancement of engine efficiency, reduction of pollutant emissions, lower fuel consumption, and removal of cooling system from engine are the main advantages of LHR engine [20]. In order to reduce the negative aspects of 100\% WPO in diesel engine, TBC coating is needed on diesel engine hardware. The main objective of this study is the utilization of $100 \%$ of WPO in diesel engine without using diesel. In this investigation, the usability and constancy of $100 \%$ of WPO as fuel in a lanthana-doped partially stabilized zirconia coated diesel engine and uncoated diesel engine were investigated. Operating parameters were compared between coated and uncoated diesel engines.

\section{Materials and methods Making of WPO from waste plastic}

The waste plastic materials were collected from various solid waste management sectors and cut down into small piece of size approximately $0.50-1.2 \mathrm{~cm}^{2}$. Water was used to wash the plastic materials in order to remove the dirt and foreign particles and kept them in an electric oven at 100 to $120^{\circ} \mathrm{C}$ for removing moisture. Dried plastic material mixed with $10 \%$ of coal and $1 \%$ of silica as catalyst was fed into pyrolytic reactor under inert nitrogen atmosphere. The mixture then undergoes pyrolysis at the temperature of 450 to $500{ }^{\circ} \mathrm{C}$ at atmospheric pressure, monitored by PID controller. After 4 to $5 \mathrm{~h}$, the plastic vapor coming out from the reactor unit passes through a double walled condenser. The WPO is

Table 1 LHR engine exhaust emission compared to conventional engine fueled with biodiesel using plasma spray coating technique

\begin{tabular}{|c|c|c|c|c|c|c|c|c|}
\hline \multirow{2}{*}{$\begin{array}{l}\text { Standard/base engine } \\
\text { specifications }\end{array}$} & \multirow{2}{*}{ TBC material } & \multirow{2}{*}{$\begin{array}{l}\text { Operating } \\
\text { condition }\end{array}$} & \multicolumn{5}{|c|}{ Exhaust emissions } & \multirow[t]{2}{*}{ Referenc } \\
\hline & & & $\begin{array}{l}\text { Exhaust gas } \\
\text { temperature }\end{array}$ & smoke & $\mathrm{NOx}$ & $\mathrm{CO}$ & $\mathrm{HC}$ & \\
\hline Ricardo E6-MS/128/76 & $\mathrm{MgO}-\mathrm{ZrO}_{2}$ & Variable speed & - & Reduction & Increase & - & Reduction & {$[15]$} \\
\hline Kirloskar-TV1 & Fly ash & $\begin{array}{l}\text { Constant speed } \\
\text { and variable load }\end{array}$ & $\begin{array}{l}\text { Higher at all } \\
\text { loads }\end{array}$ & Reduction & Increase & - & Reduction & {$[16]$} \\
\hline Kirloskar-TV1 & $\begin{array}{l}\text { lanthanum doped partially } \\
\text { stabilised zirconia zirconate }\end{array}$ & $\begin{array}{l}\text { Constant speed } \\
\text { and variable load }\end{array}$ & $\begin{array}{l}\text { Higher at all } \\
\text { loads }\end{array}$ & Reduction & Increase & - & Reduction & {$[17]$} \\
\hline Kirloskar, AV 1 & Lanthanum Zirconate & $\begin{array}{l}\text { Constant speed } \\
\text { and variable load }\end{array}$ & - & Reduction & Increase & $\begin{array}{l}\text { At higher load } \\
\text { CO increases }\end{array}$ & Reduction & [18] \\
\hline Rainbow-186 diesel & $\mathrm{ZrO}_{2}$ & Variable speed & - & - & Increase & $\begin{array}{l}\text { At higher load CO } \\
\text { increases }\end{array}$ & Reduction & {$[19]$} \\
\hline $\begin{array}{l}\text { Ford } 6.0 \mathrm{lt} \text {. T/C, } \\
\text { intercooling, direct } \\
\text { injection }\end{array}$ & $\mathrm{CaZrO}_{3}$ & Variable speed & - & Reduction & Increase & - & Reduction & {$[20]$} \\
\hline
\end{tabular}


condensed by water and collected in a separate tank. ASTM techniques were used to estimate the fuel properties of diesel and WPO and test results are shown in Table 2.

\section{Conversion of conventional engine in TBC engine}

LHR engine performance is based on the properties of the coating materials. TBC materials must possess the following properties such as lower thermal conductivity, lower specific heat, higher strength, higher thermal shock resistance, fracture toughness, higher expansion coefficient, higher temperature capability, chemical inertness and high resistance to erosion and corrosion. Survey of literature reveals that various ceramic materials are being utilized for TBC in LHR engines. Coating materials used so far in $\mathrm{CI}$ engine include zirconium oxide $\left(\mathrm{ZrO}_{2}\right)$, calcium zirconite $\left(\mathrm{CaZrO}_{3}\right)$, partially stabilized zirconia (PSZ), $\mathrm{Al}_{2} \mathrm{O}_{3}$, mullite and $\mathrm{TiO}_{2}$, yttria stabilized zirconia (YSZ), among others [21].

However, the usage of zirconium in LHR engine is limited. Pure zirconia modifies its phases in three crystal forms at various temperatures. At temperature more than $2350^{\circ} \mathrm{C}$ it has a cubic structure, between 1175 to $2370^{\circ} \mathrm{C}$ it has tetragonal structure and below $1160^{\circ} \mathrm{C}$, it is transformed into monoclinic structure. Transformation from tetragonal to monoclinic is rapid due to the change in temperature. In this transformation, the volume is increased from 3 to $6 \%$ thereby making cracks in the material [22]. In a CI engine, operating temperature varies from 600 to $2000^{\circ} \mathrm{C}$. Hence pure zirconia is not a suitable material for LHR engine. The crystal structure changes of zirconium can be prevented by mixing with suitable metal oxides, which will retard or reduce these crystal structure alterations and increase the stability of cubic structure [23].

Zirconia is mixed with metal oxides of $\mathrm{MgO}$ or $\mathrm{Y}_{2} \mathrm{O}_{3}$ in order to maintain its cubic structure at various temperatures. Cubic stabilized zirconia is a valuable ceramic

Table 2 Properties of diesel and waste plastic oil

\begin{tabular}{llll}
\hline Properties & Test Method & Diesel & WPO \\
\hline Density@ 15 ${ }^{\circ} \mathrm{C}\left(\mathrm{kg} \mathrm{m}^{-3}\right)$ & IS1448, P16 & 840 & 830 \\
Kinematic viscosity @ 40 ${ }^{\circ} \mathrm{C}(\mathrm{CSt})$ & ASTM D445 & 2.15 & 3.3 \\
Flash point $\left({ }^{\circ} \mathrm{C}\right)$ & IS1448, P20 & 45 & 40 \\
Fire point $\left({ }^{\circ} \mathrm{C}\right)$ & IS1448, P20 & 56 & 49 \\
Gross calorific value $\left(\mathrm{kJ} \mathrm{kg}{ }^{-1}\right)$ & IS1448, P25 & 46,200 & 44,200 \\
Cetane Number & IS1448, P9 & 54 & 48 \\
Carbon (wt\%) & - & 84.7 & 81.7 \\
Hydrogen (wt\%) & - & 13.7 & 10.7 \\
Nitrogen (wt\%) & - & 1.15 & 2.49 \\
Sulphur (wt\%) & - & 0.44 & 0.49 \\
Oxygen (wt\%) & - & 0.03 & 4.31 \\
\hline
\end{tabular}

material, which does not experience destructive phase changes throughout heating and cooling. In the present investigation, magnesium oxide is selected to mix with zirconium based on the availability and cost. Zirconia is mixed with $10 \% \mathrm{MgO}$ and then it is called PSZ.

PSZ is widely used as TBC material, due to its lower thermal conductivity and phase stability at working temperatures more than $1200^{\circ} \mathrm{C}$ [24]. However, addition of $10 \% \mathrm{MgO}$ increases the tendency of sintering, hence improvement of the quality of the coating is done by doping small amount of Lanthanum Oxide $\left(\mathrm{La}_{2} \mathrm{O}_{3}\right)$ with PSZ. This will reduce the thermal conductivity and resistance to sintering. Therefore, in the present investigation, coating material is selected as PSZ with addition of $\mathrm{La}_{2} \mathrm{O}_{3}$. The coating on the engine components was done by using plasma spray method. This method is most suitable, precise and effective for coating on the diesel engine combustion hardware components.

Plasma spray method comprises of material as powder infused through a high temperature plasma fire, where it is quickly warmed and speedup the process. This hot material impact on the substrate surface quickly chills off and immediately starts framing of coating. Plasma gun comprises of copper anode and tungsten cathode and both are water-cooled. Plasma gas streams around the cathode and through the anode form a nozzle. In this plasma spray method argon is utilized as bearer gas and hydrogen is utilized as auxiliary gas.

CI engine combustion chamber components were coated by lanthana-doped PSZ for a thickness of $300 \mu \mathrm{m}$ over a $100 \mu \mathrm{m}$ thick $\mathrm{Al}_{2} \mathrm{TiO}_{5}$ bond coat by plasma spray method. Before coating, the surface has to be sand blasted to make outside roughness of $5 \mu \mathrm{m}$, which is measured by using roughness tester PCE-RT 11. Then it was cleaned by anhydrous ethanol and dried in cool air. $\mathrm{Al}_{2} \mathrm{TiO}_{5}$ powder was injected to get the first coating of bond on the sand blasted substrate. This warm material contacts on the substrate surface to form $100 \mu \mathrm{m}$ thick coating.

In the same way the next layer of lanthana-doped PSZ coating of thickness $300 \mu \mathrm{m}$ was done. Thus, the total coating thickness comes to $400 \mu \mathrm{m}$. The same process is followed on all other combustion elements. To keep the compression ratio of the engine as same before and after coating, a suitable grinding should be done on engine components before coating.

The pictorial representation of the coated and uncoated engine components is shown in Fig. 1a-d.

\section{Experimental procedure}

In this investigation, single cylinder, constant speed, naturally aspirated, four stroke, DI-CI engine was used. The detailed engine parameters are presented in Table 3. Layout of the test rig along with all measuring equipment and instruments are shown in Fig. 1e. 


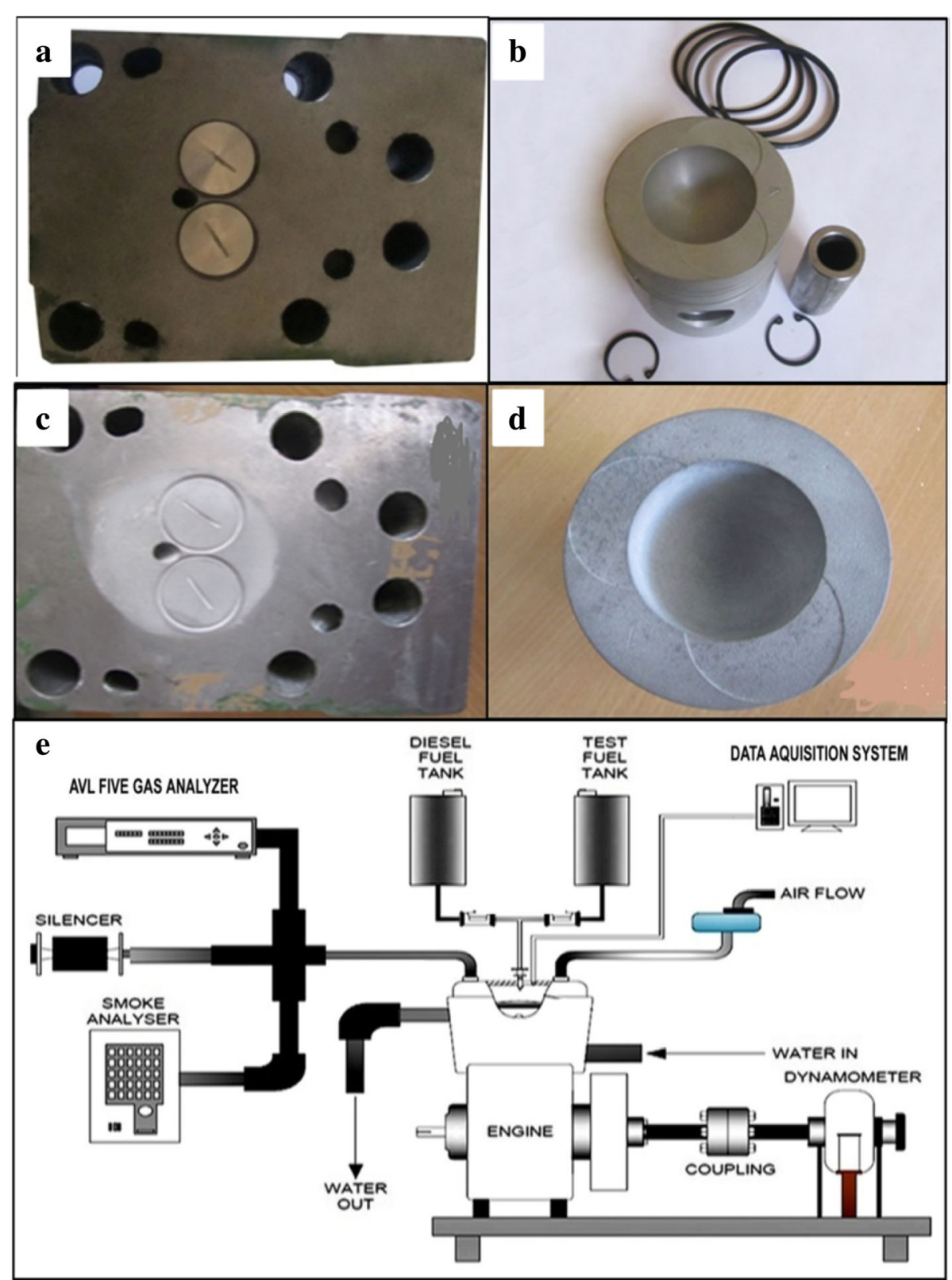

Fig. 1 Diesel engine hardware components (a) uncoated cylinder head and valves, (b) uncoated piston, (c) coated cylinder head and valves, (d) coated piston and (e) experimental layout

The initial condition of fuel level in the tank, engine oil level, coolant level and other manufacturer settings of the engine are checked and noted. The engine is permitted to run till it reaches a stable condition. After that, load is applied gradually from no-load to full-load. All other measuring equipments are switched on and the necessary settings are made as per the instruction given in the manual. The application of load is done at six levels and other measurements such as $\mathrm{HC}, \mathrm{CO}$, smoke opacity, $\mathrm{NO}_{\mathrm{x}}$, pressure crank angle (CA) and heat release rate (HRR) are measured and recorded. The list of instruments and their accuracy along with percentage of uncertainties is presented in Table 4 [25].

\section{Results and discussion}

BSFC

BSFC is a ratio of fuel consumed by the engine to power produced by the engine. Variation of BSFC with brake power for WPO and diesel for conventional and LHR engine is shown in Fig. 2a. It is observed from the graph that BSFC decreases with increase of brake power for both diesel and WPO. This is due to the fact that under 
Table 3 Specifications of the engine

\begin{tabular}{ll}
\hline Manufacturer & Kirloskar oil engines limited \\
\hline Model & TV1 \\
Type of Engine & Vertical, 4-Stroke, DI-Cl engine \\
Method of loading & Eddy current dynamometer \\
Rated power & $5.2 \mathrm{~kW}$ \\
Speed & $1500 \mathrm{rpm}$ \\
Compression Ratio & $17.5: 1$ \\
Injection pressure & $22 \mathrm{MPa}$ \\
Bore and stroke & $87.5 \times 110(\mathrm{~mm})$ \\
\hline
\end{tabular}

same experimental conditions engine has consumed more quantity of fuel at higher loads. Decrease of residence time of the combustion gases and increase of volumetric efficiency are other reasons for decrease in the BSFC. It is also noticed that the BSFC is decreased more in LHR engine than that of uncoated engine by the reason of higher in-cylinder gas and wall temperatures which improves the combustion. Shortening ignition delay time due to coating is another reason for decrease in BSFC [26]. At the maximum load, the BSFC of WPO in LHR engine is $0.31 \mathrm{~kg} \mathrm{kWh}{ }^{-1}$. It is $0.02 \mathrm{~kg} \mathrm{kWh}^{-1}$ less than that of WPO without coating. This is due to decrease in heat transfer by reason of ceramic coating.

\section{BTE}

BTE is the direct indication of diesel engine conversion capacity of heat from fuel to mechanical energy. BTE of the diesel engine fueled by WPO and diesel for LHR and uncoated engine are shown in Fig. 2b. Engine BTE depends upon the heating value and specific gravity of the fuel. It is concluded that BTE increases with brake power for diesel and WPO in LHR engine than uncoated engine. This is because of heat transferred through combustion elements is reduced by ceramic coating and also increase in in-cylinder gas and wall temperature [27]. Hence, combustion is developed and thus improves the
BTE. Another reason is that reduction of BSFC leads to improvement in BTE. It is also noticed that at higher load, BTE for WPO in coated engine is $33 \%$ and it is $2 \%$ higher than that of diesel in coated engine. This may be due to additional quantity of fuel burnt at higher load [28]. It is also noticed that oxygen presents in the WPO causes complete combustion.

\section{Exhaust gas temperature (EGT)}

Figure 2c exhibit the effect of EGT with brake power for LHR and conventional engine fueled with diesel and WPO. EGT increases with increase of brake power for LHR engine but not in conventional engine. This might be the reason of decrease in heat losses with effect of ceramic insulation which transfers heat into exhaust gas [29]. EGT rises as a result of combustion which extends from power stroke to the exhaust stroke in the cylinder [30]. It is viewed that EGT of WPO in LHR engine is $410{ }^{\circ} \mathrm{C}$ and it is $15^{\circ} \mathrm{C}$ less than that of WPO in conventional engine.

\section{Co}

The effects of $\mathrm{CO}$ emission with brake power on LHR and uncoated engine fueled by WPO and diesel are indicated in Fig. 2d. CO is a toxic gas produced because of poor combustion due to insufficient oxygen supply. Low flame temperature and rich mixture are also the reasons for higher $\mathrm{CO}$. The $\mathrm{CO}$ emission is reduced with increase of brake power for both engines, but after $80 \%$ of load, the $\mathrm{CO}$ emission is suddenly raised and it reaches maximum for coated and un-coated diesel engine fueled by diesel and WPO. It is because of accumulation of more fuel at higher load and insufficient combustion time. At full load, CO emission of WPO is $0.22 \%$, which is $0.12 \%$ lesser than that of diesel in conventional engine. This is due to more oxygen present in the WPO, which leads to better combustion and oxidation of $\mathrm{CO}$ into $\mathrm{CO}_{2}$ [31]. It is also found that at the maximum load, $\mathrm{CO}$ of WPO in LHR engine is $0.2 \%$, which is $0.02 \%$ lesser

Table 4 List of instruments and their accuracy along with percentage of uncertainties [25]

\begin{tabular}{|c|c|c|c|c|}
\hline Measurement & Type \& manufacturer & Measurement technique & Accuracy (\%) & Uncertainty \\
\hline Load & Strain gauge, Sensotronics Sanmar & Load cell & $\pm 10 N$ & \pm 0.2 \\
\hline Speed & Kubler, Germany & Magnetic pickup principle & $\pm 10 \mathrm{rpm}$ & \pm 0.1 \\
\hline Fuel flow measurement & Differential pressure transmitter & Volumetric measurement & $\pm 0.1 \mathrm{~cm}^{3}$ & \pm 1 \\
\hline $\mathrm{CO}$ & AVL exhaust gas analyser, Austria & NDIR technique & $\pm 0.02 \%$ & \pm 0.2 \\
\hline $\mathrm{HC}$ & AVL exhaust gas analyser, Austria & NDIR technique & $\pm 0.03 \%$ & \pm 0.1 \\
\hline NOx & AVL exhaust gas analyser, Austria & NDIR technique & $\pm 12 \mathrm{ppm}$ & \pm 0.2 \\
\hline Smoke & AVL smoke meter & Opacimeter & $\pm 1 \mathrm{HSU}$ & \pm 1 \\
\hline EGT indicator & Make Wika & Thermocouple & $\pm 1^{\circ} \mathrm{C}$ & \pm 0.15 \\
\hline Pressure pick up & PCB, piezotronics & Magnetic pickup principle & $\pm 1 \mathrm{~kg}$ & \pm 0.1 \\
\hline Crank angle encoder & Kubler, Germany & Magnetic pickup principle & $\pm 1 \mathrm{deg}$ & \pm 0.2 \\
\hline
\end{tabular}



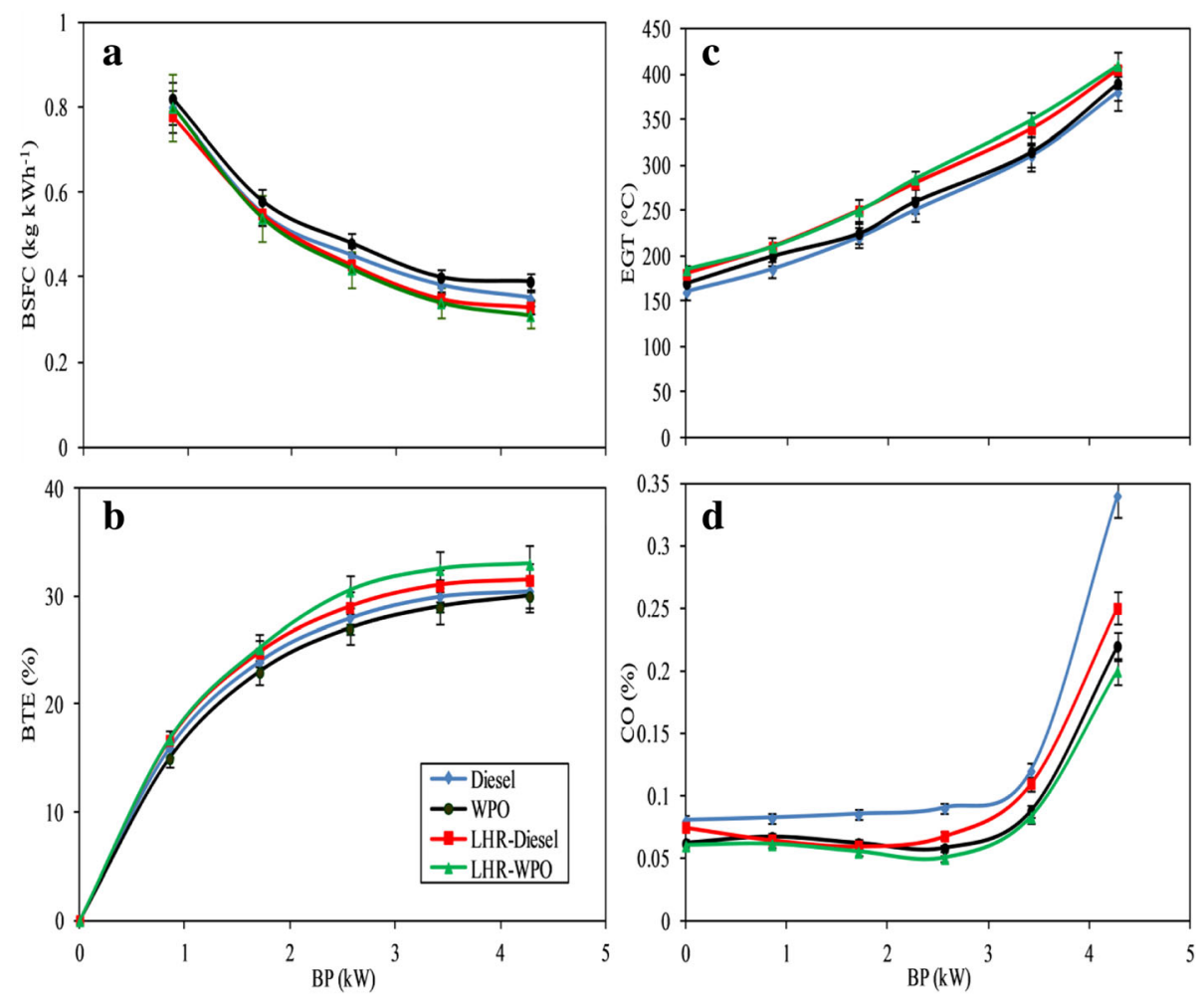

Fig. 2 Performance evaluation as a function of BP for all test fuels on coated and uncoated engines (a) BSFC, (b) BTE, (c) EGT and (d) CO.

than that of WPO in the conventional engine. It is because of higher temperature of gas that reduces the level of pre-mixed combustion. It leads to decrease the initial formation of CO. WPO exhibits longer ignition delay due to its lower cetane number and higher aromatic content, thus it shortens the combustion period.

HC

$\mathrm{HC}$ emission is lower for LHR engine because of shorter quenching distance associated with leaner flammability limit. Figure 3a shows the comparison of $\mathrm{HC}$ emission with brake power for LHR and conventional engine fueled with WPO and diesel: HC emission of LHR engine is less as compared to uncoated engine. This is because of increase of in-cylinder temperature with the effect of reduction in heat transfer to cooling system of the engine [32]. It is noticed that WPO has less HC emission than that of diesel in the uncoated and LHR engine. This is due to more oxygen present in WPO than that of diesel (Table 2). It has been noticed that at the maximum load in LHR engine, WPO shows $32 \mathrm{ppm}$ of $\mathrm{HC}$ emission, which is $10 \mathrm{ppm}$ less than that of WPO in uncoated engine. Addition of ceramic coating compensates the poor volatility property of WPO. It increases the evaporation rate and enhances the mixing of fuel with air, which leads to improve combustion and reduction of $\mathrm{HC}$ emission [33].
$\mathrm{NO}_{x}$

Effects of $\mathrm{NO}_{x}$ emission on coated and conventional engine fueled with diesel and WPO are indicated in Fig. 3c. From the figure it is observed that $\mathrm{NO}_{\mathrm{x}}$ continuously increases with brake power due to increase of in-cylinder heat. The $\mathrm{NO}_{\mathrm{x}}$ emission is higher in LHR engine than uncoated engine [34], due to ceramic coating that increases the combustion temperature and combustion duration. The $\mathrm{NO}_{\mathrm{x}}$ emission of LHR engine fueled with WPO at higher load is $980 \mathrm{ppm}$, which is $90 \mathrm{ppm}$ higher than that of WPO in conventional engine. This is due to the ceramic coating which causes shorter ignition delay and contents of oxygen molecules in WPO lead to an increase in $\mathrm{NO}_{\mathrm{x}}$ emission.

\section{Smoke opacity}

Normally, smoke is not visible from engine exhaust and it is visible because of sluggish or incomplete combustion and as a negative indicator of engine operation. The effects of smoke on coated and conventional engine fueled with WPO and diesel are shown in Fig. 3b. Smoke opacity increases with increase of brake power, this is because of quantity of fuel supplied for every unit time increases [35]. The smoke is less in LHR engine fueled by WPO than that of conventional engine. This is as a result of higher in-cylinder gas and wall temperature than that of conventional engine. Also, at higher load in 

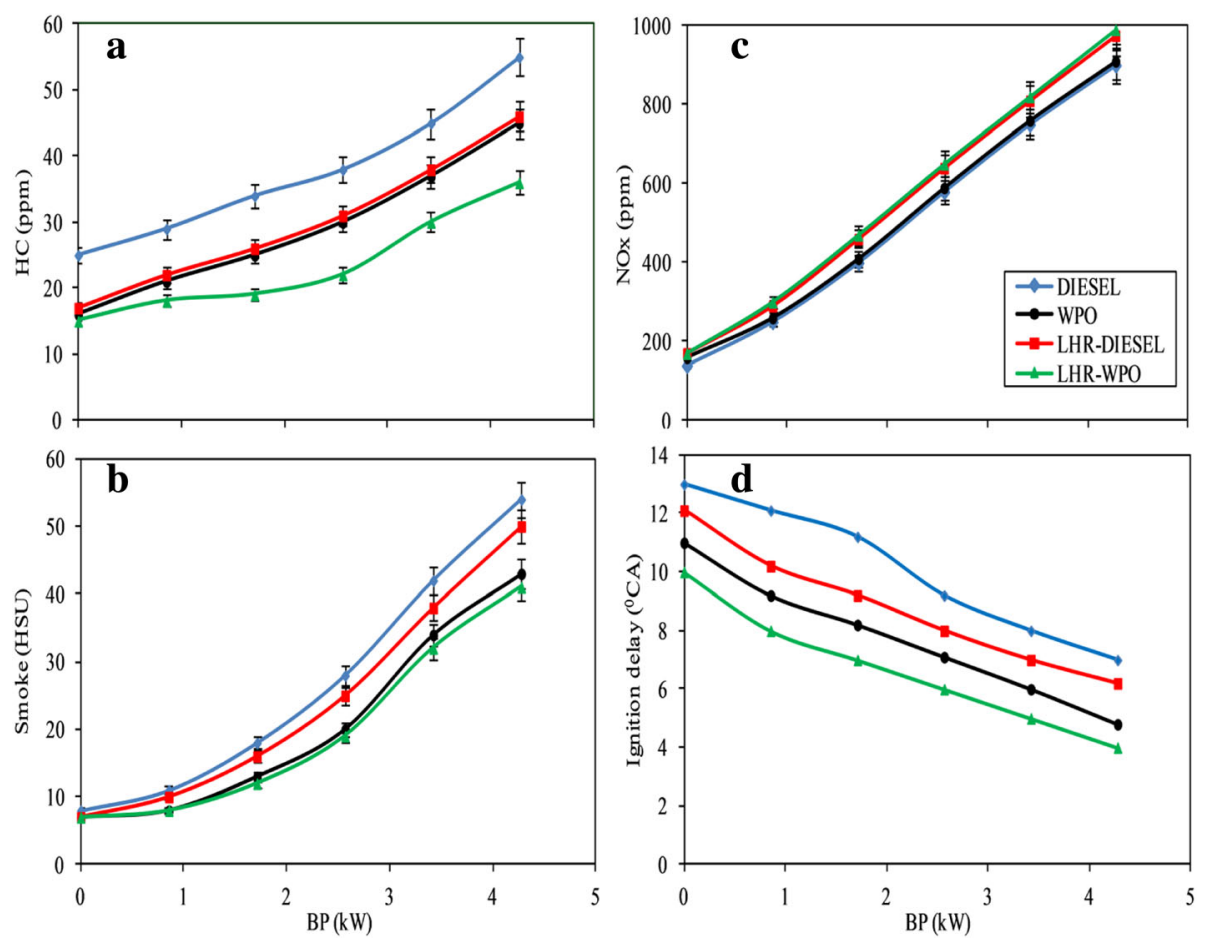

Fig. 3 Performance evaluation as a function of BP for all test fuels on coated and uncoated engines (a) HC, (b) Smoke, (c) $\mathrm{NO}_{x}$ and (d) ignition delay

LHR engine, smoke emission of WPO is 41 Hartridge Smoke Unit (HSU), which is $10 \mathrm{HSU}$ lesser than that of diesel in conventional engine. This is because of more oxygen present in the WPO that leads to better combustion.

\section{Ignition delay}

Ignition delay is one of the significant parameter for analyzing the combustion process in diesel engine. The intermediate time period between start of fuel injection and start of combustion is calculated in diesel engine and it is termed as ignition delay. Effect of ignition delay with brake power on coated and uncoated engine fueled by diesel and WPO is indicated in the Fig. 3d. Ignition delay is lower for WPO than diesel in both engines due to lower compressibility and higher viscosity of WPO. [36]. Further, the ignition delay for WPO in LHR engine decreased from 10 to $8{ }^{\circ} \mathrm{CA}$, as brake power increased from zero to $4 \mathrm{~kW}$. This is lower than that of WPO fueled in uncoated diesel engine, which has decreased from 13 to $7{ }^{\circ} \mathrm{CA}$. This is because of higher combustion temperature by ceramic coating that leads to shorten ignition delay.

\section{Peak cylinder pressure}

In-cylinder pressure estimation is thought to be an exceptionally significant source of data amid the advancement and adjustment phases of diesel engine.
In-cylinder pressure can also be used to calculate other engine operating parameters such as indicated mean effective pressure, HRR, combustion period and so on [37]. Figure 4a shows the changes of cylinder peak pressure with $\mathrm{CA}$ on coated and uncoated engine fueled by diesel and WPO at the maximum engine load. Combustion begins earlier for coated engine than conventional engine due to shorter ignition delay and advanced injection timing of coated engine. Further, peak pressure for LHR engine is high as compared to conventional engine for both fuels. This is because of higher operating temperature and earlier heat release in the combustion chamber. It is noticed that cylinder pressure of LHR engine fueled by WPO is higher than diesel in conventional engine. This might be due to higher density and cetane index in WPO which improves the in-cylinder pressure.

\section{HRR}

Effect of HRR on coated and conventional engine fueled with WPO and diesel is indicated in Fig. 4b. HRR was estimated based on the average data of 100 cycles of engine operation. At the beginning of combustion, HRR is lower for all fuels. This might be due to vaporization of fuel through ignition delay period which decreases the temperature [38]. In premixed combustion stage, heat release rate is more for uncoated engine for both fuels 

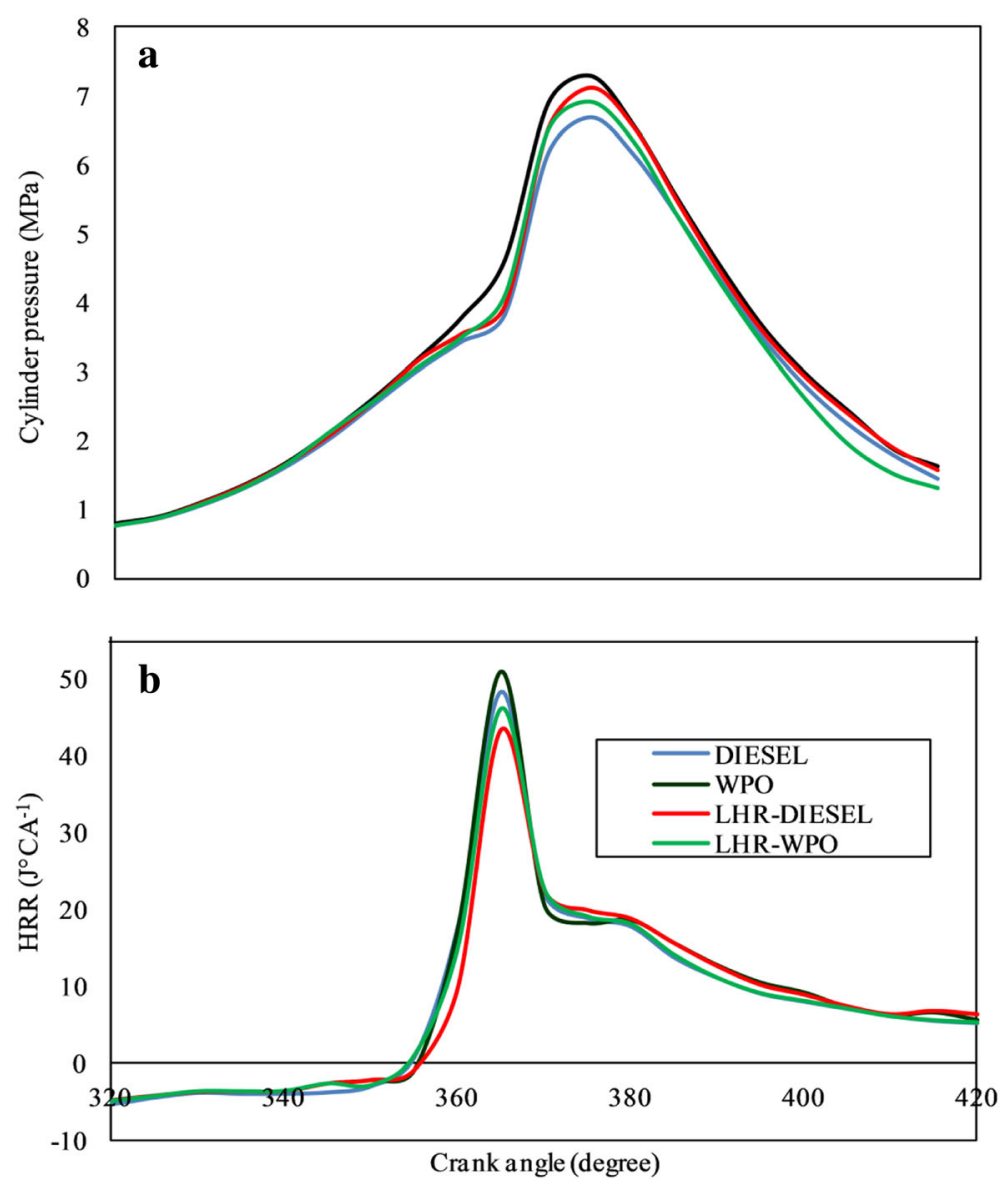

Fig. 4 Variations of (a) cylinder pressure and (b) heat release rate as a function of crank angle at full load

compared to coated engine. This is on account of longer ignition delay that admits more quantity of fuel. Hence, higher HRR was achieved [16]. HRR for WPO and diesel in uncoated engine are 50 and $46 \mathrm{~J}^{\circ} \mathrm{CA}^{-1}$ respectively. This is because of higher fuel-air ratio of WPO as compared to diesel. However, in diffusive combustion phase, the combustion is progressed and higher HRR is observed for LHR engine for both fuels. This might be due to insulation effect of coating that increases the in-cylinder temperature.

\section{Conclusions}

The main objective of this study is that diesel engine can be run by alternative fuel without using diesel that has been achieved through LHR engine fueled with WPO. For that purpose, engine combustion hardware elements were coated by ceramic material of lanthanadoped PSZ. More heat has accumulated in the combustion chamber with the effect of insulation coating, thus enhancing the performance and reducing the emission drastically.

In light of the outcomes of this examination, the subsequent specific end results were drawn:
- Pyrolysis process was used for preparation of WPO.

- The significant improvement in BTE in LHR engine fueled with neat WPO was achieved. At higher load, BTE for WPO in coated engine is $33 \%$ and it was $3 \%$ higher compared to WPO in uncoated engine.

- The BSFC and CO emission were lower in LHR engine than in conventional engine for both fuels.

- The HC emission and smoke of LHR engine were less than that of conventional engine. This is because of more amount of heat accumulated in the combustion chamber.

- The $\mathrm{NO}_{\mathrm{x}}$ emission was higher for WPO in uncoated engine due to higher oxygen content of WPO. $\mathrm{NO}_{\mathrm{x}}$ emission further increased in LHR diesel engine fueled with WPO. This is on account of higher in cylinder temperature caused by insulation coating.

In short, WPO fueled LHR diesel engine is better as compared to diesel engine fueled with diesel except in higher $\mathrm{NO}_{\mathrm{x}}$ emission. 


\section{Acknowledgements}

The authors would like to thank and express gratitude to Dr. R. Senthil, Dean University College of Engineering, Anna University, Villupuram, Tamilnadu, INDIA and also peers who were instrumental in providing their rich experience.

\section{Authors' contributions}

SE is the main author who wrote the ideas and interpreted the results of the manuscript. BP is responsible for the data collection, analysis and presentation. Both authors read and approved the final manuscript.

\section{Competing interests}

The authors declare that they have no competing interests.

\section{Publisher's Note}

Springer Nature remains neutral with regard to jurisdictional claims in published maps and institutional affiliations.

\section{Received: 27 February 2018 Accepted: 2 November 2018}

\section{Published online: 19 March 2019}

\section{References}

1. Abdullah SRNR, Ariyani D, Nata IF. Conversion of palm oil sludge to biodiesel using alum and $\mathrm{KOH}$ as catalysts. Sustain Environ Res. 2017;27: 291-5.

2. Arbab MI, Masjuki HH, Varman M, Kalam MA, Imtenan S, Sajjad H. Fuel properties, engine performance and emission characteristic of common biodiesels as a renewable and sustainable source of fuel. Renew Sust Energ Rev. 2013;22:133-47.

3. Agarwal AK. Biofuels (alcohols and biodiesel) applications as fuels for internal combustion engines. Prog Energ Combust. 2007;33:233-71.

4. Heywood JB. Internal combustion engine fundamentals. New York: McGraw-Hill; 1988.

5. Jain S, Sharma MP. Biodiesel production from Jatropha curcas oil. Renew Sust Energ Rev. 2010;14:3140-7.

6. Othman MF, Adam A, Najafi G, Mamat R. Green fuel as alternative fuel for diesel engine: a review. Renew Sust Energ Rev. 2017:80:694-709.

7. Mahmudul HM, Hagos FY, Mamat R, Adam AA, Ishak WFW, Alenezi R. Production, characterization and performance of biodiesel as an alternative fuel in diesel engines - a review. Renew Sust Energ Rev. 2017;72:497-509.

8. Rinaldini CA, Mattarelli E, Savioli T, Cantore G, Garbero M, Bologna A. Performance, emission and combustion characteristics of a IDI engine running on waste plastic oil. Fuel. 2016;183:292-303.

9. Kumar S, Prakash R, Murugan S, Singh RK. Performance and emission analysis of blends of waste plastic oil obtained by catalytic pyrolysis of waste HDPE with diesel in a Cl engine. Energ Convers Manage. 2013;74: 323-31.

10. Kaimal VK, Vijayabalan P. A detailed study of combustion characteristics of a DI diesel engine using waste plastic oil and its blends. Energ Convers Manage. 2015;105:951-6.

11. Gungor C, Serin H, Ozcanli M, Serin S, Aydin K. Engine performance and emission characteristics of plastic oil produced from waste polyethylene and its blends with diesel fuel. Int J Green Energy. 2015;12:98-105.

12. Panda AK, Murugan S, Singh RK. Performance and emission characteristics of diesel fuel produced from waste plastic oil obtained by catalytic pyrolysis of waste polypropylene. Energ Source Part A. 2016;38:568-76.

13. Mani M, Nagarajan G, Sampath S. Characterisation and effect of using waste plastic oil and diesel fuel blends in compression ignition engine. Energy. 2011;36:212-9.

14. Lapuerta M, Fernandez JR, Agudelo JR. Diesel particulate emissions from used cooking oil biodiesel. Bioresour Technol. 2008;99:731-40.

15. Parlak A, Yasar H, Hasimoglu C, Kolip A. The effects of injection timing on $\mathrm{NO}_{x}$ emissions of a low heat rejection indirect diesel injection engine. Appl Therm Eng. 2005;25:3042-52.

16. MohamedMusthafa M, Sivapirakasam SP, Udayakumar M. Comparative studies on fly ash coated low heat rejection diesel engine on performance and emission characteristics fueled by rice bran and pongamia methyl ester and their blend with diesel. Energy. 2011;36:2343-51.

17. Mittal N, Athony RL, Bansal R, Kumar CR. Study of performance and emission characteristics of a partially coated LHR SI engine blended with nbutanol and gasoline. Alexandria Eng J. 2013;52:285-93.
18. Kumar DV, Kumar PR, Kumari MS. Prediction of performance and emissions of a biodiesel fueled lanthanum zirconate coated direct injection diesel engine using artificial neural networks. Procedia Eng. 2013;64:993-1002.

19. Hazar $\mathrm{H}_{1}$ Ozturk $\mathrm{U}$. The effects of $\mathrm{Al}_{2} \mathrm{O}_{3}-\mathrm{TiO}_{2}$ coating in a diesel engine on performance and emission of corn oil methyl ester. Renew Energ. 2010;35:2211-6.

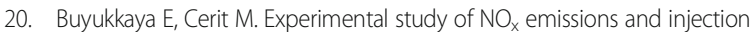
timing of a low heat rejection diesel engine. Int J Therm Sci. 2008;47:1096-106.

21. Sharma TK. Performance and emission characteristics of the thermal barrier coated SI engine by adding argon inert gas to intake mixture. J Adv Res. 2015;6:819-26.

22. Jiang L, Guo SQ, Qiao MR, Zhang M, Ding WZ. Study on the structure and mechanical properties of magnesia partially stabilized zirconia during cyclic heating and cooling. Mater Lett. 2017;194:26-9.

23. Borik MA, Bublik VT, Kulebyakin AV, Lomonova EE, Milovich FO, Myzina VA, et al. Phase composition, structure and mechanical properties of PSZ (partially stabilized zirconia) crystals as a function of stabilizing impurity content. J Alloy Compd. 2014;586:S231-5.

24. Shinohara T, Fujii T, Tohgo K, Shimamura Y. Densification process in fabrication of PSZ-Ti composites by spark plasma sintering technique. Mater Charact. 2017;132:230-8.

25. Senthil R, Sivakumar E, Silambarasan R. Effect of diethyl ether on the performance and emission characteristics of a diesel engine using biodieseleucalyptus oil blends. RSC Adv. 2015;5:54019-27.

26. Jena SP, Acharya SK, Das HC, Patnaik PP, Bajpai S. Investigation of the effect of $\mathrm{FeCl}_{3}$ on combustion and emission of diesel engine with thermal barrier coating. Sustain Environ Res. 2018;28:72-8.

27. Abedin MJ, Masjuki HH, Kalam MA, Sanjid A, Ashraful AM. Combustion, performance, and emission characteristics of low heat rejection engine operating on various biodiesels and vegetable oils. Energ Convers Manage. 2014:85:173-89.

28. Sivakumar G, Kumar SS. Investigation on effect of Yttria stabilized zirconia coated piston crown on performance and emission characteristics of a diesel engine. Alexandria Eng J. 2014;53:787-94.

29. Kathirvelu B, Subramanian S, Govindan N, Santhanam S. Emission characteristics of biodiesel obtained from jatropha seeds and fish wastes in a diesel engine. Sustain Environ Res. 2017;27:283-90.

30. Wang WG, Lyons DW, Clark NN, Gautam M, Norton PM. Emissions from nine heavy trucks fueled by diesel and biodiesel blend without engine modification. Environ Sci Technol. 2000;34:933-9.

31. Kalargaris I, Tian GH, Gu S. The utilisation of oils produced from plastic waste at different pyrolysis temperatures in a DI diesel engine. Energy. 2017; 131:179-85.

32. Musthafa MM. Development of performance and emission characteristics on coated diesel engine fuelled by biodiesel with cetane number enhancing additive. Energy. 2017;134:234-9.

33. Iscan B, Aydin H. Improving the usability of vegetable oils as a fuel in a low heat rejection diesel engine. Fuel Process Technol. 2012;98:59-64.

34. Hazar H. Characterization and effect of using cotton methyl ester as fuel in a LHR diesel engine. Energ Convers Manage. 2011;52:258-63.

35. Patnaik PP, Jena SP, Acharya SK, Das HC. Effect of $\mathrm{FeCl}_{3}$ and diethyl ether as additives on compression ignition engine emissions. Sustain Environ Res. 2017:27:154-61.

36. Shahabuddin M, Liaquat AM, Masjuki HH, Kalam MA, Mofijur M. Ignition delay, combustion and emission characteristics of diesel engine fueled with biodiesel. Renew Sust Energ Rev. 2013;21:623-32.

37. Rajasekar E, Selvi S. Review of combustion characteristics of $\mathrm{Cl}$ engines fueled with biodiesel. Renew Sust Energ Rev. 2014;35:390-9.

38. Aydin S, Sayin C. Impact of thermal barrier coating application on the combustion, performance and emissions of a diesel engine fueled with waste cooking oil biodiesel-diesel blends. Fuel. 2014;136:334-40. 